\title{
Holy Springs and Protestantism in early modern Denmark: A Medical Rationale for a Religious Practice
}

\author{
JENS CHR V JOHANSEN*
}

We know of some 650 holy springs in Denmark. Their abundance seems to be the reason why a decade ago one of Denmark's leading authorities on late-medieval archaeology wrote that the popular worship of saints in that country appeared to be more closely connected to the cult of holy springs than anywhere else in Europe. ${ }^{1}$ This statement was apparently based largely on post-Reformation sources. A very different picture emerges from the Danish archaeologist Susanne Andersen's close scrutiny of medieval sources and from her archaeological excavations. Nearly all the documentation for the existence of holy springs belongs to the era after the Reformation. ${ }^{2}$ As far as the attitude of the religious and political authorities is concerned, we can trace a development from a total rejection of holy springs during the late sixteenth century, to a reluctant tolerance, and finally to a complete acceptance during the late seventeenth century. In this paper the reasons for this development will be addressed. ${ }^{3}$

\section{Holy Springs before and after the Reformation}

Holy springs have, indeed, been associated with Danish saints like Knud Lavard (Duke Canute), Holy Niels and Saint Kjeld. Canonization records include lists of miracles from the twelfth and thirteenth centuries which are noted as having occurred in connection with such springs. Of these, the site of only one, that associated with Knud Lavard, has been documented, although there are some suggestive references regarding that associated with Holy Niels. ${ }^{4}$

Written sources of the fourteenth and fifteenth centuries contain no references to holy springs, although modern scholars have persistently argued that springs and pilgrimageshrines were closely connected. The Spring of the Holy Trinity on the island of Lolland is used as an example. A letter dated 1464 mentions that the parishioners had begun building

* Dr Jens Chr V Johansen, Dalgas Boulevard 72-3, DK-2000 Frederiksberg, Denmark.

This article is a revised version of a paper delivered at the Cambridge Wellcome Unit for the History of Medicine on 6 March 1995. I should like to thank Stuart Clark of University College Swansea, David Harley, Christian D Nøkkentved of Illinois Mathematics and Science Academy, and Jacob Thomsen of the Royal Library (Copenhagen) for their comments.
1 Niels-Knud Liebgott, Hellige maend og kvinder, Højbjerg, Worminianum, 1981, p. 34.

2 Susanne Andersen, 'Helligkilder og valfart', in Ebba Waaben, et al. (eds), Fromhed og verdslighed $i$ middelalder og renaissance. Festskrift til Thelma Jexlev, Odense Universitetsforlag, 1985, pp. 32-44.

3 The research on Danish holy springs hardly deals with the sixteenth and seventeenth centuries; see August F Schmidt, Danmarks Helligkilder, København, Det Schønbergske Forlag, 1926.

4 Andersen, op. cit., note 2 above, p. 37. 


\section{Jens Chr V Johansen}

a chapel in the western part of Vestenskov parish. While this chapel caused disputes about dues and services between the local pastor and the bishop, there are no references to a spring in the records: it was not until 1570, after the Reformation, that anyone mentioned it. What is unclear is whether the chapel was built because of a holy spring or the spring became holy because of the chapel. ${ }^{5}$

Another case is the spring and church at Karup in Jutland. A church was built there during the 1480s, and from papal letters we know that it was the destination of many pilgrims drawn by the miracles said to have taken place in and around the church. In 1505 , Queen Christine of Denmark visited Karup, and her account book lists sums of money paid to the church, to sellers of pilgrim-badges and to the priests who performed Mass. Not until 1623, however, is there any mention of a spring. The fame of Karup as a pilgrims' shrine was probably due to a picture of a weeping Madonna in the church, which also appears on the pilgrim-badge. ${ }^{6}$

At Kippinge, on the island of Falster, there is supposed to have been another holy spring. Its history is especially interesting with regard to the effect of the Reformation on the use of holy springs. From at least the late fifteenth century, when a miracle was said to have occurred there, pilgrims had travelled to Kippinge church. Thieves were said to have stolen the tabernacle, with the consecrated host, but they were miraculously prevented from leaving the churchyard. ${ }^{7}$ Kippinge church made a great deal of money from pilgrims, so much so that King Christian II borrowed large sums from it. Even foreign pilgrims made their way there. ${ }^{8}$

Some scholars have argued that after the Reformation the focus shifted from the shrine in the church to the spring outside. There is, however, no evidence to support this. Around 1610, Rasmus Pedersen, a former pastor of the church, wrote a small unpublished pamphlet in which he attacked the superstition that led people to go on pilgrimage to Kippinge. Not only did he not mention a spring, he wrote ". . . there is an altarpiece, which gave it [the church] honour and credence enough. It is a painting of God the Father as an old man with a grey beard and a crown on his head, and the Holy Ghost as a dove figure over both their heads [sic]."9 In 1629 Kirstine Munk, King Christian IV's morganatic wife, visited Kippinge. When, in a letter, the king later complained of her behaviour, it is quite clear that she entered the church to look at the altarpiece, ${ }^{10}$ yet there is no mention of a spring.

Some time before 1674, Niels Pedersen Saxtrup, chaplain of the church in Nakskov, wrote a small tract attacking the use of Kippinge as a place of pilgrimage, and again we find no mention of a spring there, although he referred to springs elsewhere in the text. ${ }^{11}$ Two other small treatises, written during the last quarter of the seventeenth century by

5 Ibid., p. 38.

6 Ibid., p. 39.

7 H F Rørdam, 'Om Valfarterne til Kippinge før og efter Reformationen', Kirkehistoriske Samlinger, 1893, 4 (3): 433-86, p. 438.

8 Ibid., p. 446.

9 The minister Hans Mule quoted the unpublished pamphlet 'Noli peccare' by Rasmus Pedersen in his 'Qvid in hoc usque tempus observaverim de Kippinge templo'. The Royal Library (Copenhagen), Thottske Samling nr. 1434 og 1435.

\footnotetext{
10 Rørdam, op. cit. note 7 above, pp. 456-7.

11 Rigsarkivet (National Archive, Copenhagen, hereafter RA), Håndskriftsamlingen I. Langebeks Samling II, Topografiske Samlinger: Niels Pedersen Saxtrup, 'Underviisning om Sathans bedrægeri med de Siugis Helbredelse ved Kippinge Kircke i Falster', where he wrote, "even if the devil often haunts such springs and fountains just as he does the church of Kippinge" [thi om end skjønt djefwelen tit oc ofte lige saa wel spøger wed saadanne kilder oc vandspring som wed Kippinge kirke].
} 


\section{Holy Springs and Protestantism in early modern Denmark}

Lutheran pastors Ole Andersen Smidt and Hans Mule from the neighbouring parishes of Dannemare and Landet, defended the special character of Kippinge church, but neither pastor mentioned a spring. ${ }^{12}$ However, the most telling piece of evidence comes in a letter of 1687 from the three secular members of a commission for the distribution of tithes for the islands of Falster and Lolland. Surprisingly, they suggest that the idolatry taking place at Kippinge church should be stopped, as "neither the earth contains minerals, nor are there special springs which by divine providence and blessings could heal the sick". ${ }^{13}$ The fourth member of the commission, Thomas Kingo, Bishop of Lolland-Falster and a famous composer of Danish hymns, objected to the letter, as the commission had no brief to deal with idolatry. He defended the practices at Kippinge, stressing the use of sermons to teach the worshippers, but he did not mention a spring. Kingo wrote that such special churches and sites should not be considered as having an inherent force. Only God has such power, and He can help where and whenever He wishes. ${ }^{14}$ Not until 1707 do we find a reference to a special or holy spring at Kippinge. In that year, Magnus Hosum, a student of theology wrote about it in his book De templi Kippingensis after reading a dissertation on the physic of healing springs. This dissertation, however, discusses a spring near Elsinore and another called Helene also on Zealand, but not the one at Kippinge. ${ }^{15}$ The story of the Kippinge Spring ends some time in the early 1800 s, when it dried up and visits to it ceased.

Two kinds of silence, archaeological and theological, suggest that holy springs were of little or no importance during the Middle Ages. While many coins and pieces of pottery have been found at places identified as holy springs, few of the artifacts are of medieval origin. ${ }^{16}$ Moreover, early Danish reformers such as Hans Tavsen and Peder Palladius never referred to the existence of holy springs in their copious writings on superstition, published during the $1550 \mathrm{~s}^{17}$

The first written reference made to a spring dates from the 1560 s. In 1565 the town of Elsinore banned washing of laundry "in or over the spring" located just outside the town. ${ }^{18}$ From the 1570s, both printed and manuscript records include increasingly frequent references to special water sources. In 1570 King Frederik II wrote the first known decree prohibiting superstitious belief in the power of springs. In a letter to the royal administrator at Aalholm Castle, Frederik stated that he had learned of the abuses and idolatry practised by the many worshippers who went to the chapel and nearby spring called Holy Trinity in the parish of Vesternæs. He wanted such practices to stop, so that nobody else should learn from this evil example, and therefore ordered the royal

12 Olai Andr. Smidt, 'Dissertatio de Sanatione Extraordinaria, qvæ fit in Templo Kippingensi apud Falsteros, ex verbo Dei instituta', and Mule, op. cit., note 9 above.

13 Landsarkivet for Sjælland m.v. (The Provincial Archive of Zealand), Lolland-Falsters Stiftsarkiv: 'Kommissionsakt angaaende tienden paa LollandFalster', fol. 36r.

14 The Royal Library, Thottske Samling nr. 730: "Kgl. anbefalet Kommissionsakt angaaende Tiendernes og Gejstlighedens Indkomsters Forandring 1687 i Laaland og Falster". Letter written by Bishop Thomas Kingo, dated 12 September 1687.
15 This was the work by Fochardus With, Schediasma psycicum [sic] de fontibus medicatis, published in 1697 in Copenhagen.

16 Andersen, op. cit., note 2 above, p. 41 . In July 1995 Susanne Andersen informed me in conversation that a few late-medieval remnants of pottery have been found at the site of the Regisse Spring. Most of the pottery dates from after the Reformation, however.

17 Ibid.

18 The Provincial Archive of Zealand, Town Clerk of Elsinore's Archive, Stadsbog 1561-65, 20 July 1565 . 


\section{Jens Chr V Johansen}

administrator to do something about the spring and to tear down the chapel. The chapel remained untouched, however. ${ }^{19}$

In the late 1580s the Regisse Spring on the island of Funen is mentioned for the first time. Archaeologists have uncovered rags, crutches, hair and caps there. Such items have also been found at the Helene Spring, first mentioned in $1617 .{ }^{20}$ In the early 1620 s Ole Worm, professor of medicine and a famous antiquarian, began his register of sites of historical and antiquarian interest. To this end, he requested the parish clergy of DenmarkNorway to send him detailed reports about anything old in their parishes, and the resulting reports include, for the first time, significant amounts of information about the so-called holy springs. ${ }^{21}$ What was often stressed, however, was that although they were relics of the Catholic past, people still used them secretly. ${ }^{22}$

\section{Popular Piety}

Evidently, people's faith in miracles had not suddenly disappeared with the coming of the Reformation. Instead, ordinary people shifted their focus to the holy springs, which in Catholic times had played a rather unobtrusive and insignificant part among the wealth of possible expressions of faith in saints and miracles. Undoubtedly, the growing belief in holy springs can be considered a way of compensating for the loss of other ways of worship, ${ }^{23}$ demonstrating the relative success of the reformers and Lutheran ministers in combating superstition. Needless to say, not all Catholic rituals disappeared with the Reformation, but those that remained had been rendered harmless. Marian cults and the veneration of various saints continued quietly, not as an underground alternative to the official Lutheran faith, but rather as a supplement to the new orthodoxy.

Granting special status to certain members of the laity, especially some kings and queens, seems to have been another way in which people compensated for the loss of medieval popular piety. Such cults, while not encouraged, were certainly tolerated. For example, a dress which had allegedly belonged to Queen Margrethe I of Denmark (1375-1396) was very popular with visitors to the cathedral of Roskilde, where it was kept until King Charles X of Sweden carried it off in $1658 .^{24}$

\section{Changing Attitudes}

That attitudes were changing during the seventeenth century seems clear. The earlier harder attitude, expressed in Frederik II's order to destroy the Holy Trinity Spring, had softened significantly by 1617 when, during a visitation, Bishop Hans Poulsen Resen cautiously warned that the power of the Helene Spring ought to be attributed to the power

19 H F Rørdam, ‘Om Oprindelsen til Kappel Sogn paa Laaland', Kirkehistoriske Samlinger, 1887-89, 3(6): 460-78, pp. 466-7.

${ }^{20}$ L Daae, 'Af Provst, Mag. Peder Langes Optegnelsesbog', Kirkehistoriske Samlinger, 1893, 4(3): 618-30, pp. 628-9.

21 Jens Chr V Johansen, 'Faith, superstition and witchcraft in Reformation Scandinavia', in Ole P Grell (ed.), The Scandinavian Reformation: from evangelical Movement to institutionalisation of

\footnotetext{
Reform, Cambridge University Press, 1995, p. 191.

22 See Prasteindberetninger til Ole Worm, ed. Frank Jørgensen, 2 vols, København, Landbohistorisk selskab, 1970-1974, vol. 2, p. 146 for the Regisse Spring.

23 Andersen, op. cit., note 2 above, p. 42.

24 Kristian Erslev, 'Studier til Dronning

Margrethes Historie', (Dansk) Historisk Tidsskrift, 1881-82, 5(3): 333-425, p. 398.
} 


\section{Holy Springs and Protestantism in early modern Denmark}

of God. ${ }^{25}$ The spring near Elsinore also continued to attract people without interference from the authorities. While Bishop Jesper Brochmand, for example, suggested in 1639 that visits to springs ought to be discouraged, he never tried to intervene in any effective way. 26

Furthermore, the growing attraction of springs found an additional "natural" rationale. In 1647, the supervisor of the royal gardens, Hans Rasmussen Block, wrote in his Horticultura Danica of the spring near Elsinore from which sick people fetched sweet water to refresh themselves. ${ }^{27}$ This suggests that more and more people were directed to springs like the Helene Spring, not only because of their miraculous healing powers, but also because of the water's "natural", medical, curative potential. Visits to springs were acceptable, but the superstition still associated with them was not. This is illustrated by the punishment of a man who, in 1627 , had erected a cross at the Helene Spring, and by the argument, raised by some pastors, that the use of the spring during midsummer's night festivals should not be allowed, as it was associated with heathen rituals. ${ }^{28}$

One of the explanations for the clergy's toleration of the use of springs can undoubtedly be found in the prominent place allocated to the Creation in Reformation theology. During the seventeenth century, the idea that simple remedies could be found in nature, including certain springs, gained acceptance, even prominence. God worked not only through primary causes, but also through secondary causes-like water. Theologically, such natural curatives were gifts from God, and humankind should neither doubt nor despise them. In other words, there were no longer either theological or medical reasons for forbidding visits to springs reputed to have healing powers; indeed, such visits appear to have been encouraged, as was the search for new springs. In the light of this, the reasons for the popularity of the Helene Spring in the post-Reformation era become clearer.

Another explanation might lie in the fact that the springs were supposed to be especially effective in healing certain illnesses, in particular diseases of the eyes and rickets in children. It is very likely that the fresh water could provide some immediate relief to sufferers of eye diseases, for instance. ${ }^{29}$ As early as 1634 Pastor Peder Lange of Elsinore thought as much, and wrote that it was possible that the Helene Spring could heal diseases of the eyes and the like. However, no monkish superstition should play a part; it was permissable only to praise Jesus for the healing power God had given to the water. ${ }^{30}$

\footnotetext{
25 Daae, op. cit., note 20 above.

26 "Quin et hoc uterque aget, ut, qvi ad fontem confluunt valetudinarii, valetudinem et vitam à solo Deo in nomine Jesu unicè petant, quavis quorumvis sanctorum invocatione, tanquam qvæ Deo extremè causa sit, serìo improbata", in The Royal Library, Kallske Samling nr. 489: 'Siellandske Synodalia fra 1540 til 1639'; see also Alex Wittendorff, “"Fire stolper holder et skidehus". Tidens forestillingsverden', in Svend Ellehøj (ed.), Christian IVs verden, København, Nyt Nordisk Forlag, 1988, p. 223.

27 Hans Rasmussen Block, Horticultura Danica, hvorledis en zirlig oc nyttig Urte=Hawe $i$
}

\author{
Dannemarck kand anrettis, beprydis oc ved Mact \\ holdis, København, 1647, p. 54. \\ ${ }_{28}$ T Troels-Lund, Dagligt liv $i$ Norden $i$ det \\ sekstende Århundrede, 6th ed., Københaven, \\ Gyldendalske Boghandel nordisk Forlag, 1969, \\ vol. 7, p. 236. \\ 29 Schmidt, op. cit., note 3 above, p. 72. Eye \\ problems seem to have been cured by the greatest \\ number of wells, see Janet and Colin Bord, Sacred \\ waters. Holy wells and water lore in Britain and \\ Ireland, London, Granada, 1985, p. 35. \\ 30 Daae, op. cit., note 20 above, p. 627.
}




\section{Jens Chr V Johansen}

\section{Medical Discussions}

The custom of taking the waters became so popular that, following the suggestion of the famous Danish physician and professor of anatomy Thomas Bartholin, King Christian IV of Denmark visited the Helene Spring in 1639, and drank the water. The king was apparently unimpressed by Bishop Brochmand's warning against such visits, delivered at the provincial synod. We know, for example, that in 1640, and again in 1644, Christian IV had water brought from the spring. Some suspicions regarding the effects of the water, however, must have lurked in the king's mind. In 1645, a royal letter contained the request that seven medical doctors ${ }^{31}$ check the spring's water for metals and minerals, and that they assess its fitness as a remedy for disease. ${ }^{32}$ This clearly shows that medicinal use of the waters was empirical, rather than being dependent on therapeutic theory. It was generally accepted by then that many people had used the water to their great benefit.

In connection with the king's letter of 1645 requesting an analysis, only one of the doctors raised any doubts about the healing effects of the water from the Helene Spring. The physician Henrik Køster the Elder from the town of Nykøbing on the island of Falster wrote privately to Ole Worm asking him about the results of his investigations. Køster had heard that Dr Sperling, one of the seven doctors, had received a glass of water from the spring together with an order to analyse its composition. Dr Sperling had evaporated the water and at the bottom of the container there remained a small amount of salt-earth. Køster wanted to know if the earth contained soda or minerals. In the same letter, he stressed that people told stories about the wonderful effects of the water. ${ }^{33}$

Two weeks later, Worm replied, confirming that he also had received water from the spring for testing. He wrote that while the six other doctors had been enthusiastic in their opinions of its beneficial effects, he himself had found only a sort of marl mixed with ochre. He continued, "from this you yourself may easily figure out, what the water can do". Worm agreed that many tales of wonders were told, but added that he had not himself met anyone who by using the water of the spring had been cured of any disease. ${ }^{34}$ Whether Køster really would have been able to discover what the water contained is doubtful. Because of the deficiencies in chemical knowledge at that time, no one could know exactly the mineral composition of the spring waters being tested. ${ }^{35}$ Guesses might be made from taste or smell, but the actual therapeutic utility of any chemical or mineral could be known only from their effects. ${ }^{36}$

31 These were Christian Fabricius, doctor of law and medicine; Jacob Fabricius, physician to the court; Thomas Fincke, professor of medicine; Niels Foss, doctor of medicine and physician in Lund and Copenhagen; Simon Pauli, professor of anatomy and botany; Otto Sperling, botanist of the Botanical Garden; and Ole Worm. Fabricius, Fincke and Foss were probably symphathetically inclined towards a moderate form of Paracelsianism; Pauli and Sperling do not seem to have been specially interested in the debate.

32 RA, Danske Kancelli, Sjællandske Tegnelser, no. 28 , fol $362 b$.

33 Letter no. 1338 in H D Schepelern, Oversattelse af Breve fra og til Ole Worm, 3 vols, København, Munksgaards Forlag, 1965-1968.
34 Ibid., Letter, no. 1341.

35 Noel G Coley, "“Cures without care": "Chymical physicians" and mineral waters in seventeenth-century English medicine', Med. Hist., 1979, 23: 191-214, and idem, 'Physicians, chemists, and the analysis of mineral waters: "The most difficult part of chemistry"', in Roy Porter (ed.), The medical history of waters and spas, Medical History Supplement, No. 10, London, Wellcome Institute for the History of Medicine, 1990.

${ }^{36}$ L W B Brockliss, 'The development of the Spa in seventeenth-century France', in Porter, op. cit., note 35 above, p. 41 . 


\section{Holy Springs and Protestantism in early modern Denmark}

The analysis presumably confirmed the therapeutic value of the waters since, only a couple of months later, the royal administrator at Kronborg Castle was ordered to construct a good road between Frederiksborg and the Helene Spring. ${ }^{37}$ Official approval came a little later with the king's order that a building for the use of visitors be built near the spring. ${ }^{38} \mathrm{~A}$ by-product of the king's interest was the unhindered continuation of popular beliefs.

Royal use of the water did not end with Christian IV. In 1729, when Frederik IV was gravely ill, water was brought from the Spring of the Holy Cross in Roskilde. Although the king died, the spring's popularity at court did not diminish, and its water continued to be ordered for use by courtiers. ${ }^{39}$

\section{The Use of Holy Springs}

The construction of a visitors' building near the Helene Spring testifies to another change of attitude. Apparently, the spring was considered most effective on certain days, but not necessarily those associated with St Helene. ${ }^{40}$ If its healing power was not connected with the saint's intercession, but was an expression of the might of God, then the spring could be effective on all days, or at least not only on those linked with her. In fact, the two most popular days for visits to the Helene Spring were St John's Eve (23 June) and Walpurgis Night (30 April), which suggests a practical side to the timing of visits. ${ }^{41}$ Most of the days associated with St Helene tended to be cold, so summer was a more comfortable time to use the waters, since usual practice included getting wet and visitors often slept on the ground near the spring or at a holy spot nearby. With only one exception, all visits to springs took place during the summer. The time of day was also important. The waters were thought to be most effective in the hour after sunset and around midnight. As the two nights in June and April were associated with witches and witchcraft, visitors may also have been seeking protection from evil.

In return for being healed, visitors offered bandages and crutches as tokens of the efficacy of the springs, a practice that continued well into the eighteenth century. In addition, coins were often thrown into the water as votive offerings. ${ }^{42}$ Eventually, so as to keep an account of these offerings, the authorities set up alms boxes for the money, which was deemed to belong to the spring and collected either by its owner or by the parish pastor for distribution to the poor. From the seven records that have been preserved (four from the island of Zealand and three from the peninsula of Jutland), we can conclude that considerable amounts were donated. ${ }^{43}$ In 1731, a record was begun at the Spring of the Holy Cross in Skørping in Jutland. Together, the parish pastor and his dean, each with his own key, were to open the alms box every year at Christmas and distribute the money to the poor. However, in years when collections were small, they were to leave some money in the box. In the mid-eighteenth century, the spring dried up, but after three years the water began to run again, and the record of contributions was continued. This dry spell

37 RA, Danske Kancelli, Sjællandske Tegnelser, no. 28 , fol. 405 .

38 Wittendorff, op. cit., note 26 above, p. 222.

39 Schmidt, op. cit., note 3 above, p. 50.

40 Ibid., p. 58.

\footnotetext{
41 Ibid.

42 Ibid., pp. 70-1.

43 Ibid., pp. 54-5. For the same practice in

England, see Bord, op. cit., note 29 above, p. 71.
} 


\section{Jens Chr V Johansen}

testifies further to the popularity of the spring. We know from the Regisse Spring, for example, that so many people visited it that from time to time it simply ran dry, and water was fetched from a nearby well to fill it. $^{44}$

\section{Theological Discussion}

With the notion that God was acting through the waters, the lack of other explanations for their healing properties became less important. Ole Worm's low opinion of the Helene Spring's water apparently did not matter, because its popularity continued, so much so that, in 1650, the pastor of the nearby parish of Græsted, Erich Hansen, wrote and published his book Fontinalia sacra, which dealt especially with the Helene Spring. ${ }^{45}$

Although royal interest suggests that the medical effects of the water were what attracted visitors, Hansen's book gave equal importance to popular views of its miraculous healing powers. ${ }^{46}$ Even though the Church expressed some scepticism about the water's healing qualities, nobody could deny that almost everyone accepted that it produced real effects. As a ban on visits to holy springs could hardly be enforced, the Church chose another way to address any potential superstitions. Sermons were ordered to be said at the Helene Spring so that people could be taught the right attitude towards use of the water. ${ }^{47}$ Hansen made clear the Church's view in his book. He stressed that any healing power contained by the water must be attributed to God alone, and that superstitious practices, such as those regarding special days on which to visit, must be abandoned. All benefits were derived from God's almighty power. The sick should use the spring water begging God in the name of Jesus Christ to give it power to heal. Using some examples of effected cures, he stressed the Church's teachings about the Creation and the wonder of God's actions through nature. ${ }^{48}$

In Denmark, Reformation views on the manifestation of God's power in nature and, therefore in springs, can be found in at least two theological works: Hexaemeron rhythmico-danicum by Bishop Anders Arrebo, ${ }^{49}$ and Liber natura by Johann Arndt, published in a Danish translation in 1618. Both books included important sections on springs and their waters. Arrebo even commented on the popularity of springs in Germany, Hungary and France; for him they were a gift from God. The springs were characterized by different smells, tastes, virtues and healing powers. According to Arrebo, they attracted both kings and peasants, who drank the waters or bathed in them. Arrebo further recognized the medicinal character of springs, and mentioned cures for gout, blindness and barrenness among other things, although he was not especially precise about the waters' effects. ${ }^{50}$

Hansen connected the belief that the water of special springs had healing powers created by God to ideas about the healing abilities of plants, which suggests he had

44 Schmidt, op. cit, note 3 above, p. 66.

45 See Bengt Arvidsson, 'En helig källas teologi före och efter reformationen. Helene Kilde i Tisvilde och Erich Hansens "Fontinalia Sacra" 1650', Kirkehistoriske Samlinger, 1991: 89-116.

46 Ibid., p. 93.

47 Erich Hansen, Fontinalia sacra, det er: En kort

\footnotetext{
beretning om Helena Kilders oprindelse, brug oc missbrug udi Sieland, København, 1650, pp. $135 \mathrm{ff}$.

48 Ibid., p. 7.

49 Hexaemeron rhythmico-danicum was written around 1630, but not published until 1661, after Arrebo's death.

50 Arvidsson, op. cit., note 45 above, pp. 96-7.
} 


\section{Holy Springs and Protestantism in early modern Denmark}

Paracelsian leanings. ${ }^{51}$ Among the other theologians of the day, Arndt, at least, was influenced by Paracelsus. ${ }^{52}$ Passages from his Liber natura are quoted literally by Hansen, especially those dealing with the healing power of spring water and the effects of certain herbs. ${ }^{53}$ In fact Hansen's book was not so much a polemic against Catholic piety or superstition, as an expression of the attraction that mysticism and Paracelsianism held for Lutheran piety. ${ }^{54}$ The book shows a conscious use of the medical and philosophical ideas of the period.

Ideas similar to those of Hansen and Arndt had already appeared in a book on healing plants by Henrik Smidt of Malmø, which emphasized that God had given each region indigenous medical plants, and that there was no need to seek them abroad. ${ }^{55}$ This idea about healing plants was picked up by Arrebo as well. He wrote, as mentioned above, about springs and baths in central and western Europe, but he emphasized that mineral waters, like healing plants, were also native to Scandinavian countries. Apparently, the common assumption was that such springs and baths could be found only in other lands, but in Arrebo's view even Denmark had some. Physicians in Sweden were also searching for healing waters, and in 1678, the famous doctor Urban Hiärne found a spring that he praised as being equal to those further south. ${ }^{56}$ The activities of Hiärne may have prompted similar interests in Denmark, as a number of dissertations on springs and water written between 1680 and 1700 suggest. Among these were Joachim Frisius' Disputatio medica de aqua potu [Medical dissertation about drinking water] of 1680, Daniel Szenckeresti's Dissertatio inauguralis de aquis mineralibus salutaribus [Doctoral dissertation about healing mineral waters] from 1694, and Fochardus With's Schediasma psycicum [sic] de fontibus medicatis [A physical sketch on medicated waters] from 1697. 57

The earlier mistrust of the effects of healing springs and baths in Scandinavia may explain the apparent lack of knowledge about the growing development of spas in more southern parts of Europe, in spite of the fact that many guides to such places south of the Baltic were already being published at the end of the seventeenth century. ${ }^{58}$ Despite the interest in the Helene Spring and others like it, the tradition of taking the waters, or bathing in special springs never developed into a commercial activity of the kind found abroad. Of course, none of the promoters of the springs and spas south of the Danish borders suggested that these were the sites of miraculous intervention. ${ }^{59}$ The Danish holy springs, on the other hand, remained just that, holy; i.e. their use retained its religious connotations even into the nineteenth century. However, as more and more Danes lost

51 On Paracelsianism in Denmark see Ole P Grell, 'The reception of Paracelsianism in early modern Lutheran Denmark: from Peter Severinus, the Dane, to Ole Worm', Med. Hist., 1995, 39: 78-94, and idem, 'Caspar Bartholin and the education of the pious physician', in Ole Peter Grell and Andrew Cunningham (eds), Medicine and the reformation, London, Routledge, 1993, p. 88.

52 Grell, 'Caspar Bartholin', op. cit., note 51 above, p. 87, and Arvidsson, op. cit., note 45 above, p. 98 .

${ }_{53}$ Compare Hansen, op. cit., note 47 above, p. 30 , and Johann Arndt, Liber natura eller Naturspeyel,
København, 1618, p. 64; Hansen, pp. 30-1, and Arndt, p. 65; and Hansen, pp. 33-4, and Arndt, p. 66. 54 See Grell, 'The reception of Paracelsianism', op. cit., note 52 above, p. 87, and Arvidsson, op. cit., note 45 above, p. 100.

55 Arvidsson, op. cit., note 45 above, p. 101.

56 Ibid.

57 These dissertations have not previously been connected to the question of holy springs in Denmark.

58 Brockliss, op. cit., note 36 above, p. 43.

59 Ibid., p. 28. 
their belief in the sacred origin of the curative effects of holy springs, the popularity of foreign spas, as they were increasingly called, grew. Indeed, it became fashionable to travel to these now famous health resorts, especially to those in Germany.

Both Hansen and Hiärne built on the Paracelsian concept of the nature of human illness, and its interest in metallic remedies inevitably drew both authors to consider mineral water springs. ${ }^{60}$ Hiärne criticized people travelling at great expense, but in vain, to foreign spas, instead of staying at home and using local springs. According to him, God had provided every country with readily available remedies for disease, and especially for those illnesses indigenous to the region. ${ }^{61}$ In his book, Hansen saw the Helene Spring as an expression of God's peculiar love for Denmark. ${ }^{62}$ The spring's curative power was based on a combination of God's goodness and the natural qualities of the water. Hansen further contrasted the healing properties of the spring with the less effective medicines of some doctors. He emphasized the differences between nature's healing power and artificial medicines that tended to destroy people's health instead of curing them. ${ }^{63}$

The idea that nature's simple medicines were revealed by God probably formed the basis for the seventeenth-century popularity of springs in general and of the Helene Spring in particular. In the Church's view there could be no doubt that the springs were a gift from God; neither theological nor medical reasons ought to prevent visits to special springs, rather they should be encouraged, and more springs should be found. According to Hiärne, local parish pastors had an obligation to urge the members of their congregations to search for them. ${ }^{64}$

One hundred years after Hansen's book appeared, Dr Johannes Christian Lange published a study of water entitled Lare om de naturlige vande $e^{65}$ [Teachings about the natural waters]. In the subtitle he indicated that he had examined the various water sources in and around Copenhagen used by the general public. By contrast to Hiärne, Lange made no reference to any theological issues, rather his interest lay in water in daily use, which, he stressed, should be fresh and unpolluted. He expressed scepticism about the healing effects of special springs, although he noted that the Helene Spring had for a long time been famous as a place of healing, and he admitted, on the basis of his own analysis of the water, that it had healing properties. 66

Lange's work raised the question of the extent to which belief was seen to play a role in the curative powers of the waters. It was a problem that had also faced Hansen. He held the view that people ought to think about and praise God, who had given certain waters and plants their healing powers, and suggested that those who praised God would have more benefit from the cure than those who just took it without believing. ${ }^{67}$

60 In his Schediasma (op. cit., note 15 above) Fochardus With especially mentions the effects of the minerals in the healing springs, "cujus aqvæ qvavis æstate non inutiliter à multis hauriuntur, licet propter exiguitatem virtutum mineralium, minorem vim habeat" (p. 4).

61 Arvidsson, op. cit., note 45 above, pp. 101-2.

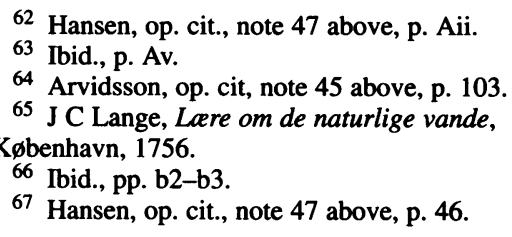




\section{Conclusion}

It can be said that the evidence for the use of special springs during the Middle Ages is slim. To be sure, it was thought for many years that pilgrims visited holy springs in Denmark more often than was the case elsewhere. On the other hand, the evidence suggests strongly that the use of holy springs, at least in Denmark, became important after the Reformation as a compensation for the loss of other, formerly acceptable, sources of miraculous healing. Due to the prominent place allocated to the Creation in Reformation theology, the use of the water from special springs came to be accepted by the Lutheran clergy, as long as any superstitions connected with a particular spring were discouraged. The acceptance of the springs even increased in the late seventeenth century as a number of medical dissertations vouched for the healing effects of their waters. 